\title{
An update on the grading of muscle injuries: a narrative review from clinical to comprehensive systems
}

\author{
ALBERTO GRASSI ${ }^{1}$, ALBERTO QUAGLIA ${ }^{2}$, GIAN LUIGI CANATA ${ }^{3}$, STEFANO ZAFFAGNINI ${ }^{1}$ \\ ${ }^{1}$ Laboratorio di Biomeccanica ed Innovazione Tecnologica, Istituto Ortopedico Rizzoli, Bologna, Italy \\ ${ }^{2}$ Ortopedia del Ginocchio e Traumatologia dello Sport, Humanitas Research Hospital, Rozzano, Milano, Italy \\ ${ }^{3}$ Centro di Traumatologia dello Sport, Ospedale Koelliker, Torino, Italy
}

\begin{abstract}
Muscle injuries are recognized to be among the most frequent injuries occurring in the sporting and athletic population, and they account for more than $30 \%$ of all injuries in professional soccer players. Despite their considerable frequency and impact, there is still a lack of uniformity in the categorization, description and grading of muscle injuries.

Dozens of systems based on clinical signs, ultrasound imaging (US) appearance or magnetic resonance imaging (MRI) findings have been proposed over the years. Most of them are three-grade systems that take into account pain, ROM limitation, swelling and hematoma, hypoechoic or hyperintense areas on US or MRI, and muscle gap or tendon involvement; however, they still lack evidence-based prognostic value. Recently, new comprehensive classification systems have been proposed, with the aim of developing uniform muscle injury terminology and giving each severity grade prognostic value.

The systems that combine detailed MRI and US features with the clinical presentation, such as the Munich Muscle Injury Classification, the ISMuLT classification, and the British Athletic Classification, if used extensively, could improve the diagnosis, prognosis and management of muscle injuries.
\end{abstract}

Keywords: grading, magnetic resonance, muscle injury, sports traumatology, ultrasound.

\section{Corresponding Author:}

Alberto Grassi, MD

Department of Biomechanics Laboratory, Istituto

Ortopedico Rizzoli

Via di Barbiano 1/10, 40136 Bologna, Italy

E-mail: alberto.grassi3@studio.unibo.it

\section{Introduction}

Muscle injuries are recognized to be among the most frequent injuries occurring in the sporting and athletic population, and they account for more than $30 \%$ of all injuries in professional soccer players (1). Despite their considerable frequency and impact, there is still a lack of uniformity in the categorization, description and grading of muscle injuries. For example, even though "muscle strain" is one of the terms most often used to refer to muscle injuries, it still lacks a clear definition and is used with a wide range of meanings. If we consider that the most widely used classifications and grading systems lack prognostic validity, it is easy to understand why, in the literature, there are several clinical and radiological systems, but none that is universally acknowledged accepted as the gold standard (2).

For the aforementioned reasons, recent years have seen several attempts to develop comprehensive classification systems, incorporating anatomical details, clinical signs and radiographic features of muscle injuries, to investigate their prognostic value through large cohort studies $(3,4)$, and to achieve uniformity in the current terminology referring to muscle injuries.

The aim of the present narrative review is to describe the different types of systems most widely used for grading muscle injury severity, which focus, respectively, on clinical signs, appearance on ultrasound imaging (US), or magnetic resonance imaging (MRI) findings, and then to present the new, comprehensive systems that will probably be used in the coming years in the field of muscle injuries in sports.

\section{Clinical grading systems}

The first attempts to grade the severity of muscle injuries were based on indirect evaluation of the muscle 


\section{Toints}

,

pathology. Traditionally, the symptoms and signs present constituted the basis for grading a given injury as "mild", "moderate" or "severe" (Tab. 1). Rachun, in 1966 (5), employed a three-grade classification that took into account the degree of pain, disability, swelling and ecchymosis and the presence of a palpable defect, and matched each grade with a supposed quantitative involvement of muscle fibers. Subsequently, other Authors integrated muscle contracture and the extent of circumference difference between the healthy and affected muscle (6), or features of the clinical history of the injury, such as the ability to continue activity after the injury (7). Later, SchneiderKolsky et al. and Malliaropoulos et al. $(8,9)$ proposed ROM deficit as the main parameter for grading hamstring injury severity.

Other Authors, attempting to better characterize the severity of the injury, considered other features such as the type of trauma, the location of the tear, and tendon, fascial sheath or musculotendinous junction involvement (10-12). However, these attempts did not generate organic, reproducible grading systems.

Generally, a grade I or "mild" muscle injury was considered to correspond to stretching or minimal disruption of muscle cells and a clinical presentation characterized by minimal, well localized pain, contracture and hemorrhage, minor disability, a full pain-free ROM (or $<10^{\circ}$ ROM deficit), and the ability to continue the sporting activity immediately after the injury.

A grade II or "moderate" injury was considered to correspond to tearing of a greater number of muscle fibers but without complete muscle rupture, and to a more severe presentation compared with the previous grade, characterized by moderate and poorly localized pain, disability, painful ROM (or $10-25^{\circ}$ ROM deficit), and inability to continue the sporting activity, with limping.

A grade III or "severe" injury was considered to be

Table 1. Clinical grading systems.

\begin{tabular}{|c|c|c|c|c|}
\hline & Rachun 1966 (5) & Wise 1977 (6) & Lee et al. 2004 (16) & $\begin{array}{l}\text { Schneider-Kolsky } \\
\text { et al. } 2006(8)\end{array}$ \\
\hline Grade I & $\begin{array}{l}\text { Localized pain, aggravated } \\
\text { by movement; minor } \\
\text { disability; mild swelling, } \\
\text { ecchymosis, local tenderness; } \\
\text { minimal hemorrhage }\end{array}$ & $\begin{array}{l}\text { Minimal pain to palpation, } \\
\text { well localized }\end{array}$ & $\begin{array}{l}\text { Small tear, }<5 \% \\
\text { loss of function }\end{array}$ & $<10^{\circ}$ ROM deficit \\
\hline Grade II & $\begin{array}{l}\text { Localized pain, aggravated by } \\
\text { movement; moderate disability; } \\
\text { moderate swelling, ecchymosis, } \\
\text { local tenderness; stretching } \\
\text { and tearing of fibers, without } \\
\text { complete disruption }\end{array}$ & $\begin{array}{l}\text { Substantial pain to palpation, } \\
\text { poorly localized; 6- } 12 \mathrm{~mm} \\
\text { difference in circumference, } \\
\text { develops within } 12-24 \text { hours; } \\
<50 \% \text { loss of ROM; } \\
\text { considerable pain on } \\
\text { contraction with considerable } \\
\text { loss of power and greatly } \\
\text { disturbed gait }\end{array}$ & $\begin{array}{l}\text { Larger tear, } 5-50 \% \\
\text { loss of function }\end{array}$ & $10-25^{\circ}$ ROM deficit \\
\hline Grade III & $\begin{array}{l}\text { Severe pain, and disability; } \\
\text { severe swelling, ecchymosis, } \\
\text { hematoma; palpable defect } \\
\text { and loss of muscle function; } \\
\text { muscle or tendon rupture }\end{array}$ & $\begin{array}{l}\text { Intractable pain to palpation, } \\
\text { diffuse; }>12 \mathrm{~mm} \text { difference in } \\
\text { circumference, develops rapidly } \\
\text { within one hour; }>50 \% \text { loss of } \\
\text { ROM; severe pain on contrac- } \\
\text { tion with almost total loss of } \\
\text { power with flicker contractions } \\
\text { and cannot weight bear }\end{array}$ & $\begin{array}{l}\text { Complete tear }>50 \% \\
\text { loss of function }\end{array}$ & $>25^{\circ} \mathrm{ROM}$ deficit \\
\hline \multicolumn{2}{|c|}{ Other features } & $\begin{array}{l}\text { Contusion } \\
\text { Strain }\end{array}$ & $\begin{array}{l}\text { Biceps } \\
\text { Not biceps }\end{array}$ & $\begin{array}{l}\text { Direct injury } \\
\text { Indirect injury }\end{array}$ \\
\hline
\end{tabular}


a complete muscle rupture, therefore presenting with the worst clinical scenario characterized by the athlete collapsing in pain immediately following the injury, more than $50 \%$ loss of motion (or $<25^{\circ}$ ROM deficit), a rapid muscle circumference decrease of more than $12 \mathrm{~mm}$ compared to the healthy contralateral muscle, diffuse pain and hemorrhage.

Although these traditional muscle injury grading systems, based on clinical presentation, might be considered attractive tools for practitioners because of their simplicity, they were based only on expert opinion and did not have established prognostic value (2).

\section{Ultrasound grading systems}

The development of imaging techniques led to the use of US in clinical practice as a means of indirectly eva- luating the anatomy and pathology of muscle injuries, thereby introducing an objective tool for characterizing and standardizing their severity. However, the first USbased grading systems were based mostly on the appearance, on US, of a specific clinical presentation (Tab. 2). In 1993, Peetrons and Creteur (13) matched a threegrade clinical severity grading system with features of US appearance: hypoechoic area length, percentage of muscle involvement and the presence of a demonstrable an-echoic gap or full-thickness tear of muscle or fascia. Two years later Takebayshi et al. (14) graded injury severity by the extent of a involvement $(<20 \%$, $20-50 \%$ or $>50 \%$ ) of the muscle cross-sectional area. Subsequently, hypervascularity around disrupted muscle fibers, intramuscular fluid collection, and the presence of detachment of adjacent fascia aponeurosis or retraction were introduced in the US-based grading of injury severity $(15,16)$. Despite these attempts to

Table 2. Ultrasound grading systems.

\begin{tabular}{|c|c|c|c|c|}
\hline & $\begin{array}{l}\text { Peetrons and Creteur } \\
1993 \text { (13) }\end{array}$ & $\begin{array}{l}\text { Takebayashi et al. } \\
1995 \text { (14) }\end{array}$ & Lee et al. 2004 (16) & Chan et al. 2012 (26) \\
\hline Grade I & Hypoechoic area & $<20 \%$ cross-sectional area & $\begin{array}{l}\text { Normal, or focal/general } \\
\text { areas of increased } \\
\text { echogenicity }+/- \\
\text { peri-fascial fluid }\end{array}$ & $\begin{array}{l}\text { Normal appearance; focal or } \\
\text { general increased } \\
\text { echogenicity with no } \\
\text { architectural distortion }\end{array}$ \\
\hline Grade II & $\begin{array}{l}5-50 \% \text { muscle involvement; } \\
\text { partial muscle rupture; } \\
\text { demonstrable hypo- } \\
\text { or an-echoic gap, with } \\
\text { "bell clapper" sign. }\end{array}$ & $\begin{array}{l}20-50 \% \text { cross-sectional } \\
\text { area }\end{array}$ & $\begin{array}{l}\text { Discontinuity of muscle } \\
\text { fibers in echogenic } \\
\text { perimyseal striae; hyper- } \\
\text { vascularity around } \\
\text { disrupted muscle fibers; } \\
\text { intramuscular fluid } \\
\text { collection; partial } \\
\text { detachment of adjacent } \\
\text { fascia or aponeurosis }\end{array}$ & $\begin{array}{l}\text { Discontinuous muscle } \\
\text { fibers; disruption site is } \\
\text { hyper-vascularized and } \\
\text { altered in echogenicity; no } \\
\text { perimyseal striation adjacent } \\
\text { to the MTJ }\end{array}$ \\
\hline Grade III & $\begin{array}{l}\text { Full-thickness tear of } \\
\text { muscle or fascia, with } \\
\text { extravasation of collection } \\
\text { away from injured part } \\
\text { of muscle; associated with } \\
\text { severe pain }\end{array}$ & $\begin{array}{l}>50 \% \text { cross-sectional } \\
\text { area }\end{array}$ & $\begin{array}{l}\text { Complete myotendinous } \\
\text { or tendo-osseous avulsion; } \\
\text { complete discontinuity of } \\
\text { muscle fibers and } \\
\text { associated hematoma; } \\
\text { "bell clapper" sign }\end{array}$ & $\begin{array}{l}\text { Complete discontinuity } \\
\text { of muscle fibers; hematoma } \\
\text { and retraction of the } \\
\text { muscle ends }\end{array}$ \\
\hline Other features & $\begin{array}{l}\text { Intrinsic } \\
\text { Extrinsic }\end{array}$ & & $\begin{array}{l}\text { Contusion } \\
\text { Strain } \\
\text { Delayed-onset muscle } \\
\text { soreness } \\
\text { Muscle hernia } \\
\text { Myositis ossificans }\end{array}$ & $\begin{array}{l}\text { Proximal MTJ } \\
\text { Muscle (proximal, middle, } \\
\text { distal) } \\
\text { Distal MTJ } \\
\text { + intramuscular } \\
\text { myofascial myotendinous }\end{array}$ \\
\hline
\end{tabular}




\section{oints}

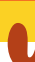

objectively describe injury severity, these classifications presented the same limitations as the simple clinical grading systems, due to the lack of any pathophysiological or prognostic value.

\section{Magnetic resonance grading systems}

Substantial improvements in the grading of muscle injuries were obtained with the introduction of MRI evaluations (Tab. 3).

Initially, three-grade systems similar to those based on US findings were used, evaluating mostly the crosssectional area involved in the lesion (14) or the extent of the tear (minimal, partial separation from the tendon or complete separation of the musculotendinous unit) (17). Subsequently, the presence of a high-signal fluid collection or hematoma, muscle retraction (18-
20) or increased intermuscular or peritendinous signal $(15,21)$ were included to establish and grade injury severity, without, however, obtaining real prognostic value. In fact, only Ekstrand et al. (22) were able to correlate hamstring injury severity, using a simple three-grade system, with return to play in professional soccer players. Other Authors succeeded in demonstrating the influence of other parameters, such as longitudinal injury length (8), volume of muscle involvement (23), cross-sectional area (24) and injury location (25), in the prognosis, yet without proposing organic and well-structured grading systems.

Therefore, in recent years, Chan et al. (26) tried to integrate location of the injury, defined as the involvement of the proximal or distal musculotendinous junction or muscle body, with precise three-grade MRI- and US-based severity assessment systems. Moreover, a further sub-classification of injuries

Table 3. Magnetic resonance grading systems.

\begin{tabular}{|c|c|c|c|c|}
\hline & $\begin{array}{l}\text { Blankenbaker and De Smet } \\
2004 \text { (18) }\end{array}$ & $\begin{array}{l}\text { Gyftopoulos et al. } \\
2008 \text { (19) }\end{array}$ & Dixon 2009 (20) & Ekstrand et al. 2012 (22) \\
\hline Grade I & $\begin{array}{l}\text { Intramuscular high signal } \\
\text { on T2 images without disruption } \\
\text { of muscle fibers; perifascial } \\
\text { fluid tracking along } \\
\text { the intermuscular region }\end{array}$ & $\begin{array}{l}\text { Focal or diffuse high } \\
\text { signal intensity at the } \\
\text { musculotendinous } \\
\text { junction; feathery } \\
\text { appearance to the muscle } \\
\text { on all pulse sequences; } \\
\text { musculotendinous } \\
\text { junction intact }\end{array}$ & $\begin{array}{l}<10 \% \text { muscle fiber } \\
\text { disruption; bright } \\
\text { signal on fluid-sensitive } \\
\text { sequences; feathery } \\
\text { appearance }\end{array}$ & $\begin{array}{l}\text { Edema but no architectural } \\
\text { distortion }\end{array}$ \\
\hline Grade II & $\begin{array}{l}\text { Myotendinous junction partially } \\
\text { torn; tendon fibers irregular } \\
\text { and thinned with mild laxity; } \\
\text { muscle edema and hemorrhage } \\
\text { with extension along the fascial } \\
\text { planes between muscle groups; } \\
\text { hematoma at myotendinous } \\
\text { junction }\end{array}$ & $\begin{array}{l}\text { Partial disruption of the } \\
\text { musculotendinous } \\
\text { junction with interstitial } \\
\text { feathery high signal or } \\
\text { hematoma; low signal in } \\
\text { chronic or old injuries }\end{array}$ & $\begin{array}{l}>10-50 \% \text { disruption } \\
\text { of muscle fibers; edema } \\
\text { and hemorrhage }\end{array}$ & $\begin{array}{l}\text { Architectural disruption } \\
\text { indicating partial tear }\end{array}$ \\
\hline Grade III & $\begin{array}{l}\text { Complete disruption of the } \\
\text { myotendinous junction; } \\
\text { extensive edema and hemorrhage }\end{array}$ & $\begin{array}{l}\text { Complete musculotendinous } \\
\text { disruption with or without } \\
\text { retraction }\end{array}$ & $\begin{array}{l}50-100 \% \text { disruption of } \\
\text { muscle fibers; complete } \\
\text { disruption and } \\
\text { discontinuity of muscle; } \\
\text { extensive edema and } \\
\text { hemorrhage; wavy } \\
\text { tendon morphology } \\
\text { and retraction }\end{array}$ & $\begin{array}{l}\text { Total muscle or tendon } \\
\text { rupture }\end{array}$ \\
\hline
\end{tabular}

Other features Direct (contusion, laceration) Indirect 
directly affecting the muscle body was suggested, specifying proximal, middle or distal location and fascial involvement. The value of this anatomical diagnosis lies in the fact that the distance of the hamstring lesion from the ischial tuberosity has been directly correlated with return to sport in sprinters (25).

However, only Cohen et al. (27) have proposed a comprehensive MRI score; this score combines six radiological observations (such as number of muscles involved, location, insertion, cross-sectional area, retraction and longitudinal axis involvement) and was found to give a value able to predict good or bad prognosis of hamstring injuries in professional football players (Tab. 4).

\section{The new comprehensive grading systems}

In 2012, fifteen international experts in the basic science of muscle injuries and sports medicine organized a consensus meeting with the endorsement of the International Olympic Committee (IOC) and the Union of European Football Associations (UEFA). Together they produced the "Munich Muscle Injury Classification" (3) (Tab. 5). This is a dichotomous classification based on the nature of the muscle trauma: direct or indirect. Moreover, indirect muscle injuries are subdivided into four types according to MRI appearance, where the Types 1 and 2 represent MRI-

Table 4. MRI-based grading system according to Cohen et al. (27).

\begin{tabular}{|c|c|c|c|c|c|}
\hline Item & Description & 0 points & 1 point & 2 points & 3 points \\
\hline 1 & $\mathrm{~N}^{\circ}$ of muscles involved & None & One muscle & Two muscles & Three muscles \\
\hline 2 & Location & - & Proximal & Middle & Distal \\
\hline 3 & Insertion & No & - & Yes & - \\
\hline 4 & Cross-sectional $\%$ of muscle involvement & $0 \%$ & $25 \%$ & $50 \%$ & $\geq 75 \%$ \\
\hline 5 & Retraction & No & & $>2 \mathrm{~cm}$ & - \\
\hline 6 & Longitudinal axis involvement & $0 \mathrm{~cm}$ & $1-5 \mathrm{~cm}$ & $6-10 \mathrm{~cm}$ & $>10 \mathrm{~cm}$ \\
\hline
\end{tabular}

Table 5. The Munich classification.

\begin{tabular}{|c|c|c|c|c|}
\hline \multicolumn{2}{|c|}{ Type of injury } & \multicolumn{2}{|c|}{ Definition and symptoms } & MRI \\
\hline \multicolumn{2}{|l|}{ Direct } & \multicolumn{2}{|c|}{$\begin{array}{l}\text { Blunt external force, muscle intact } \\
\text { Blunt external force, muscle rupture }\end{array}$} & $\begin{array}{l}\text { Hematoma } \\
\text { Hematoma }\end{array}$ \\
\hline \multirow{4}{*}{ Indirect } & \multirow[b]{2}{*}{ Functional } & $\begin{array}{l}\text { Type 1: Overexertion-related } \\
\text { 1A: Fatigue-induced muscle disorder } \\
\text { 1B: Delayed-onset muscle soreness }\end{array}$ & $\begin{array}{l}\text { lisorder } \\
\text { Muscle tightness } \\
\text { Acute inflammatory pain }\end{array}$ & $\begin{array}{l}\text { Negative } \\
\text { Negative or edema } \\
\text { only }\end{array}$ \\
\hline & & $\begin{array}{l}\text { Type 2: Neuromuscular m } \\
\text { 2A: Spine-related neuromuscular } \\
\text { muscle disorder } \\
\text { 2B: Muscle-related neuromuscular muscle disorder }\end{array}$ & $\begin{array}{l}\text { Increase of muscle tone } \\
\text { due to spinal disorder } \\
\text { Increase of muscle tone } \\
\text { due to altered } \\
\text { neuromuscular } \\
\text { control }\end{array}$ & $\begin{array}{l}\text { Negative or edema } \\
\text { only } \\
\text { Negative or edema } \\
\text { only }\end{array}$ \\
\hline & \multirow[t]{2}{*}{ Structural } & $\begin{array}{l}\text { Type 3: Partial musc } \\
\text { 3B: Moderate partial muscle tear }\end{array}$ & $\begin{array}{l}\text { Tear with small maximum } \\
\text { diameter } \\
\text { Tear with increased } \\
\text { maximum diameter }\end{array}$ & $\begin{array}{l}\text { Fiber disruption } \\
\text { Retraction and } \\
\text { hematoma }\end{array}$ \\
\hline & & $\begin{array}{l}\text { Type 4: (Sub)Total muscle } \\
\text { Complete muscle diameter involvement, defect }\end{array}$ & lsion & $\begin{array}{l}\text { Complete } \\
\text { discontinuity }\end{array}$ \\
\hline
\end{tabular}


negative functional disease, and Types 3 and 4 represent structural injuries that can be graded as minimal (Type 3a), moderate (Type 3b) or complete (Type 4). Despite the debatable use of the term "functional", and the lack of anatomical features in the classification, this system has the valuable merit of being clinically validated in terms of prognostic value for specific injuries. Indeed, this instrument represents the first time in the history of muscle injury research that a large volume of data (referring to almost 400 thigh injuries in professional soccer players) has been used to test a classification and grading system. Specifically, functional injuries were associated with a significantly shorter lay-off time compared to structural injuries (6 vs 16 days). A significant difference was found also within the indirect injuries, with a median lay-off time of 13 days for Type $3 \mathrm{a}$ (minor partial muscle tears), 32 days for Type $3 \mathrm{~b}$ (moderate partial muscle tears), and 60 days for Type 4 (complete muscle tears) (28).

At the end of 2013, the Italian Society of Muscle, Ligament and Tendons (ISMuLT) released the "ISMuLT Guidelines for muscle injuries" (29), combining the Munich classification with the anatomical location of the injury in the case of structural injuries
(Types 3 and 4). The suffixes "P", "M" or "D" were added to allow indication of proximal, middle or distal injury. A similar rationale underlies the "British Athletic Classification" (4) (Tab. 6), developed by the British Athletics Medical team which supports Great Britain's international track and field athletes. It is a five-grade system based on injury severity, and ranges from Grade 0: MRI-negative muscle soreness to Grade 4: complete muscle tear. The gravity is mostly defined by MRI cross-sectional area and length of muscle involvement, fiber disruption and clinical presentation. Moreover, each grade is further divided into two or three subgroups according to fascia (a), muscle belly (b) or tendon involvement (c). The Authors felt that inclusion of the anatomical location of the injury could be useful in order to better classify injuries and, hypothetically, allow more precise prediction of outcome. For this reason, this classification is currently being used in UK elite track and field athletes in order to provide clinical validation with a view to establishing the prognostic value of the instrument.

Finally, in 2015, the medical team of FC Barcelona, in collaboration with the Aspetar Medical Staff, also proposed an original comprehensive system named the

Table 6. The British Athletic Classification.

\begin{tabular}{|c|c|c|}
\hline Grade of injury & Definition symptoms & MRI \\
\hline \multicolumn{3}{|l|}{ Grade 0: Muscle soreness } \\
\hline 0a: Focal neuromuscular injury & Focal muscle soreness after exercise & Negative \\
\hline Ob: Generalized muscle soreness & Generalized muscle soreness & Negative or high signal \\
\hline \multicolumn{3}{|l|}{ Grade 1: Small muscle tears } \\
\hline 1a: Extend from fascia, $<10 \%$ cross-section area & No frank fiber disruption & Hematoma \\
\hline 1b: Muscle or MTJ involvement, $<10 \%$ cross-section area & No frank fiber disruption & Hematoma \\
\hline \multicolumn{3}{|l|}{ Grade 2: Moderate muscle tears } \\
\hline $\begin{array}{l}\text { 2a: Extend from fascia, } 10-50 \% \text { cross- section area, } 5-15 \mathrm{~cm} \\
\text { 2b: Muscle or MTJ involvement, } 10-50 \%\end{array}$ & Less strength reduction & Periphery high signal \\
\hline cross-section area, $5-15 \mathrm{~cm}$ & Strength reduction & High signal at MTJ \\
\hline 2c: Tendon involvement, $<50 \%$ cross- section area & Loss of tendon tension & High signal at tendon \\
\hline \multicolumn{3}{|l|}{ Grade 3: Extensive muscle tears } \\
\hline 3a: Extend from fascia, $>50 \%$ cross- section, $>15 \mathrm{~cm}$ & Sudden onset, fall to ground & Periphery high signal \\
\hline $\begin{array}{l}\text { 3b: Muscle or MTJ involvement, }>50 \% \\
\text { cross-section area, }>15 \mathrm{~cm}\end{array}$ & Sudden onset, fall to ground & High signal at MTJ \\
\hline 3c: Tendon involvement, $>50 \%,>5 \mathrm{~cm}$ & Sudden onset, fall to ground & High signal at tendon \\
\hline \multicolumn{3}{|l|}{ Grade 4: Complete muscle tears } \\
\hline 4a: Extend from fascia & Sudden onset, fall to ground, palpable gap & Periphery defect \\
\hline 4b: Muscle or MTJ involvement & Sudden onset, fall to ground, palpable gap & Defect at MTJ \\
\hline 4c: Tendon involvement & Sudden onset, fall to ground, palpable gap & Defect at tendon \\
\hline
\end{tabular}


"MLG-R Classification" (30). This system describes injuries on the basis of the direct " $\mathrm{D}$ " or indirect " $\mathrm{I}$ " mechanism (M), proximal " $p$ ", middle " $m$ " or distal "d" location $(\mathbf{L})$ in the case of direct injuries, and involvement of tendon "T", muscle-tendon junction "J" or muscle periphery " $F$ " in the case of indirect injuries (followed by proximal "p" or distal "d" location). The severity of the injury is also evaluated through a 0 to 4 grading scale $(\mathbf{G})$ of cross-sectional area involvement. Finally, the first or recurrent condition $(\mathbf{R})$ is described as first episode "R0", first re-injury "R1", second reinjury "R2" and so on. With the MLG-R acronym these Authors offer the possibility of describing the injury, its location and its chronological evolution.

\section{Conclusions}

Muscle injury classifications and grading systems are currently undergoing a continuous evolution. To date, numerous systems, often without an evidencebased rationale, have lacked prognostic value and therefore represented sub-optimal tools for the clinicians involved in the management of muscle injuries. In the last few years, however, growing understanding of the features of muscle injuries and their correlation with return to sport has allowed the development of more comprehensive and detailed systems potentially able to improve prediction of the prognosis of a given injury. However, further studies are needed to validate the new grading systems and to expand existing knowledge on muscle injury pathogenesis, diagnosis and prognosis in the light of modern technological improvements.

\section{References}

1. Woods C, Hawkins RD, Maltby S, et al. Football Association Medical Research Programme. The Football Association Medical Research Programme: an audit of injuries in professional football-analysis of hamstring injuries. Br J Sports Med. 2004;38:36-41.

2. Hamilton B, Valle X, Rodas G, et al. Classification and grading of muscle injuries: a narrative review. Br J Sports Med. 2015;49:306.

3. Mueller-Wohlfahrt HW, Haensel L, Mithoefer K, et al. Terminology and classification of muscle injuries in sport: the Munich consensus statement. Br J Sports Med. 2013; $47: 342-350$.
4. Pollock N, James S, Lee JC, et al. British athletics muscle injury classification: a new grading system. Br J Sports Med. 2014;48:1347-1351.

5. Rachun A. Standard Nomenclature of Athletic Injuries. American Medical Association, Chicago, Illinois. 1966.

6. Wise DD. Physiotherapeutic treatment of athletic injuries to the muscle-tendon complex of the leg. Can Med Assoc J. 1977;117:635-639.

7. Oakes BW. Hamstring muscle injuries. Aust Fam Physician. 1984;13:587-591.

8. Schneider-Kolsky ME, Hoving JL, Warren P, et al. A comparison between clinical assessment and magnetic resonance imaging of acute hamstring injuries. Am J Sports Med. 2006;34:1008-1015.

9. Malliaropoulos N, Isinkaye T, TsitasK, et al. Reinjury after acute posterior thigh muscle injuries in elite track and field athletes. Am J Sports Med. 2011;39:304-310.

10. Page E. Athletic Injuries and Their Treatment. Arco Publications, London 1962.

11. Haldeman K, Soto-Hall R. Injuries to muscles and tendons. JAMA 1935;104:2319-2324.

12. O'Donoghue DH. Treatment of Injuries to Athletes. First Edition. W.B. Saunders Company, Philadelphia 1962.

13. Peetrons P, Creteur P. Echographies et traumatismes musculaires aigus. In: Chevrot A, Kahn M, Morvan Gv (Eds) Imagerie Des Parties Molles De L'Appareil Locomoteur. Sauramps Medical, Montpellier. 1993;229-235.

14. Takebayashi S, Takasawa H, Banzai Y, et al. Sonographic findings in muscle strain injury: clinical and MR imaging correlation. J Ultrasound Med. 1995;14:899-905.

15. Rodas G, Pruna R, Til L, et al. Clinical Practice Guide for muscular injuries. Epidemiology, diagnosis, treatment and prevention. Apunts Med Esport. 2009;64:179-203.

16. Lee JC, Healy J. Sonography of lower limb muscle injury. AJR Am J Roentgenol. 2004;182:341-351.

17. Rubin SJ, Feldman F, Staron RB, et al. Magnetic resonance imaging of muscle injury. Clin Imaging. 1995;19:263-9.

18. Blankenbaker DG, De Smet AA. MR imaging of muscle injuries. Appl Radiol. 2004;33:14-26.

19. Gyftopoulos S, Rosenberg ZS, Schweitzer ME, et al. Normal anatomy and strains of the deep musculotendinous junction of the proximal rectus femoris: MRI features. AJR Am J Roentgenol. 2008;190:W182-W186.

20. Dixon J. Gastrocnemius vs. soleus strain: how to differentiate and deal with calf muscle injuries. Curr Rev Musculoskelet Med. 2009;2:74-77.

21. Lee JC, Mitchell AW, Healy JC. Imaging of muscle injury in the elite athlete. Br J Radiol. 2012;85:1173-1185.

22. Ekstrand J, Healy JC, Waldén M, et al. Hamstring muscle injuries in professional football: the correlation of MRI findings with return to play. Br J Sports Med. 2012;46:112-117.

23. Slavotinek JP, Verrall GM, Fon GT. Hamstring injury in athletes: using MR imaging measurements to compare extent of muscle Injury with amount of time lost from competition. AJR Am J Roentgenol. 2002;179:1621-1628.

24. Gibbs NJ, Cross TM, Cameron M, et al. The accuracy of MRI in predicting recovery and recurrence of acute grade one hamstring muscle strains within the same season in Australian Rules football players. J Sci Med Sport. 2004; 7:248-58. 
25. Askling CM, Tengvar M, Saartok T, et al. Acute first-time hamstring strains during high-speed running: a longitudinal study including clinical and magnetic resonance imaging findings. Am J Sports Med. 2007;35:197-206.

26. Chan O, Del Buono A, Best TM, et al. Acute muscle strain injuries: a proposed new classification system. Knee Surg, Sports Traumatol Arthrosc. 2012;20:2356-2362.

27. Cohen SB, Towers JD, Zoga A, et al. Hamstring injuries in professional football players: magnetic resonance imaging correlation with return to play. Sports Health. 2011;3:423-430.
28. Ekstrand J, Askling C, Magnusson H, et al. Return to play after thigh muscle injury in elite football players: implementation and validation of the Munich muscle injury classification. Br J Sports Med. 2013;47:769-774.

29. Maffulli N, Oliva F, Frizziero A, et al. ISMuLT Guidelines for muscle injuries. Muscles Ligaments Tendons J. 2014;3:241-249.

30. Valle X, Tol H, Hamilton B. Muscle Injury Classification. 2015. From Muscle Injuries Clinical Guide 3.0. http://muscletechnetwork.org/wp-content/uploads/2015/04/MUSCLEINJURIES-CLINICAL-GUIDE-3.0-LAST-VERSION.pdf 